\title{
Pelaksanaan Ibadah Minggu (Live Recording \& Live Streaming) di GPIB Bahtera Hayat Surabaya
}

\author{
Timothy John Pattiasina ${ }^{1^{*}}$, Raymond Sutjiadi ${ }^{2}$, Benny Rahmawan Noviadji ${ }^{3}$, Edwin Meinardi \\ Trianto $^{4}$, Briantito Adiwena ${ }^{5}$, Arjuna Bangsawan ${ }^{6}$, Eddy Triswanto Setyoadi ${ }^{7}$ \\ ${ }^{1,7}$ Program Studi Sistem Informasi, Institut Informatika Indonesia, Surabaya, Jawa Timur \\ ${ }^{2}$ Program Studi Teknik Informatika, Institut Informatika Indonesia, Surabaya, Jawa Timur \\ 3,6 Program Studi Desain Komunikasi Visual, Institut Informatika Indonesia, Surabaya, Jawa Timur \\ ${ }^{4}$ Program Studi Manajemen Informatika, Institut Informatika Indonesia, Surabaya, Jawa Timur \\ ${ }^{5}$ Program Studi Desain Produk, Institut Informatika Indonesia, Surabaya, Jawa Timur \\ Email: ${ }^{1}$ temmy@ikado.ac.id, ${ }^{2}$ raymond@ikado.ac.id, ${ }^{3}$ benny@ikado.ac.id, ${ }^{4}$ edwin@ikado.ac.id, \\ briantito@ikado.ac.id, 6arjuna@ikado.ac.id, 7 eddy@ikado.ac.id,
}

(Naskah masuk: 23 April 2021, direvisi: 28 April 2021, diterima: 03 Mei 2021)

\begin{abstract}
Abstrak
GPIB (Gereja Protestan di Indonesia bagian Barat) adalah bagian dari GPI (Gereja Protestan Indonesia) yang dulunya bernama Indische Kerk. Saat ini GPIB sendiri memiliki 326 gereja yang bernaung dalam kelompok musyawarah pelayanan (Mupel) GPIB. Salah satunya adalah GPIB Bahtera Hayat Surabaya. GPIB Bahtera Hayat Surabaya yang berkedudukan di daerah Surabaya bagian Utara memiliki jumlah anggota jemaat sekitar 663 jiwa. Pada saat merebaknya kasus Corona Virus Diseases 2019, atau lebih dikenal dengan sebutan COVID-19 di Indonesia, khususnya di Surabaya pada awal bulan Maret tahun 2020, berdampak pada pelaksanaan Ibadah Minggu di gereja tersebut. Banyak anggota jemaat yang menjadi khawatir untuk hadir beribadah dan memilih untuk tidak mengikuti Ibadah Minggu di GPIB Bahtera Hayat Surabaya. Berdasarkan hal tersebut GPIB Bahtera Hayat Surabaya mencoba untuk mengembangkan konsep baru untuk pelayanan ibadah minggu mereka dalam bentuk live recording dan live streaming.
\end{abstract}

Kata Kunci: GPIB Bahtera Hayat Surabaya, Ibadah Minggu, Live Recording, Live Streaming

\section{Sunday Service (Live Recording \& Live Streaming) at GPIB Bahtera Hayat Surabaya}

\begin{abstract}
GPIB (Protestant Church in Western Indonesia) is part of the GPI (Indonesian Protestant Church) which was formerly known as the Indische Kerk. Currently, GPIB itself has 326 churches that are part of the GPIB ministry deliberation group (Mupel). One of them is GPIB Bahtera Hayat Surabaya. GPIB Bahtera Hayat Surabaya, which is located in the northern part of Surabaya, has a congregation of about 663 people. At the time of the outbreak of the Corona Virus Diseases 2019 case, or better known as COVID-19 in Indonesia, especially in Surabaya in early March 2020, it had an impact on the implementation of Sunday Worship at the church. Many members of the congregation are worried about attending services and choose not to attend the Sunday Service at GPIB Bahtera Hayat Surabaya. Based on this situation, GPIB Bahtera Hayat Surabaya tries to develop new concept of their Sunday worship service in the form of live recording and live streaming.
\end{abstract}

Keywords: GPIB Bahtera Hayat Surabaya, Ibadah Minggu, Live Recording, Live Streaming 


\section{PENDAHULUAN}

GPIB Bahtera Hayat Surabaya yang beralamatkan di jalan Laksda M.Natzir, Tanjung Perak, adalah salah satu gereja Protestan di Surabaya yang berdiri sejak tahun 1969. Hingga saat ini perkembangan kehidupan pelayanan di gereja tersebut mengalami pasang surut, khususnya terkait dengan jumlah jemaat yang dilayani yang sedikit banyak menurun, sebagai akibat dari banyaknya jemaat yang telah pindah ke wilayah luar Surabaya. Akan tetapi banyak dari jemaat tersebut yang hadir pada beberapa pelaksanaan Ibadah Minggu yang diselenggarakan oleh GPIB Bahtera Hayat Surabaya, walaupun tidak selalu rutin pada kenyataannya.

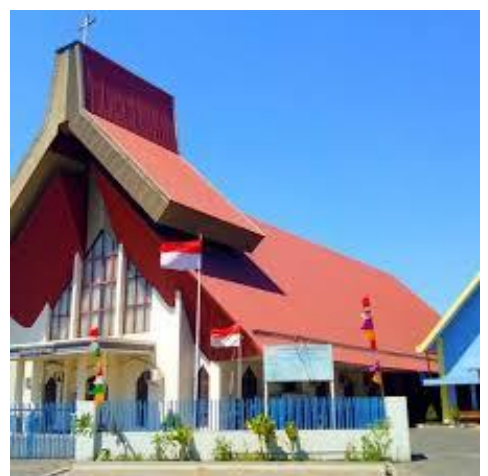

Gambar 1. Gedung Gereja GPIB Bahtera Hayat Surabaya

Di awal bulan Maret tahun 2020, virus Corona melanda Sebagian besar negara di dunia. Dampak yang dirasakan dalam kehidupan berjemaat di GPIB Bahtera Hayat Surabaya cukup terasa. Dalam hal ketakutan warga jemaat untuk hadir pada Ibadah Minggu di gereja, mengakibatkan penurunan yang drastis angka kehadiran jemaat. Hal ini tentu saja menjadi perhatian utama dari ketua majelis jemaat (KMJ) GPIB Bahtera Hayat Surabaya, bapak Pendeta Marianus Tupessy, S.Th. untuk dapat mencari solusi terbaik agar pelaksanaan pelayanan Ibadah Minggu tetap dapat dilakukan dan diikuti oleh seluruh warga jemaatnya. Terkait dengan solusi tersebut, KMJ GPIB Bahtera Hayat Surabaya, bapak Pendeta Marianus Tupessy, S.Th. Th menyampaikan usulan untuk merubah pelaksanaan Ibadah Minggu di gereja dalam bentuk Ibadah Minggu secara daring (dalam jaringan). Konsep daring ini menjadi suatu terobosan baru dalam dunia pelayanan ibadah, dan tentu membutuhkan proses serta usaha dalam prakteknya.

Salah satu dosen Institut Informatika Indonesia (IKADO) Surabaya, bapak Timothy John Pattiasina, yang merupakan anggota jemaat yang terdaftar di GPIB Bahtera Hayat Surabaya, merasa terpanggil untuk memberikan bantuan untuk menyelenggarakan pelaksanaan Ibadah Minggu dalam bentuk Live Recording serta Live Streaming. Hal ini tentu saja selaras dengan solusi yang diusulkan oleh KMJ GPIB Bahtera Hayat Surabaya. Dalam pertemuan yang digagas oleh pihak GPIB Bahtera Hayat Surabaya dengan pihak IKADO Surabaya yang diwakali oleh bapak Timothy John Pattiasina berhasil menyepakati kerjasama dalam bentuk pengabdian masyarakat di GPIB Bahtera Hayat Surabaya untuk menyelenggarakan Ibadah Minggu dalam bentuk Live Recording serta Live Streaming. Dari pertemuan tersebut, pihak gereja GPIB
Bahtera Hayat Surabaya mengirimkan surat permohonan kepada pihak IKADO Surabaya untuk meminta bantuan dari tim dosen IKADO dalam pelaksanaan Ibadah Minggu secara Live Recording maupun Live Streaming.

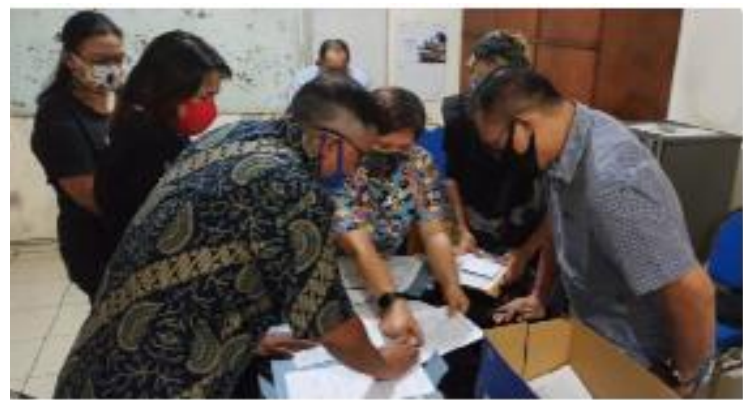

Gambar 2. Suasana Pertemuan Majelis Jemaat GPIB Bahtera Hayat Surabaya dengan Perwakilan IKADO Surabaya

\section{METODOLOGI KEGIATAN}

Setelah menerima surat permohonan dari pihak gereja, bapak Timothy John Pattiasina menghubungi kepala Pusat Penelitian dan Pengabdian Masyarakat (P3M) IKADO Surabaya untuk meminta bantuan surat tugas pelaksanaan kegiatan pengabdian masyarakat di GPIB Bahtera Hayat Surabaya. Selanjutnya, bapak Timothy John Pattiasina menghubungi beberapa dosen dari Fakultas Teknologi Informasi dan Fakultas Desain di IKADO Surabaya guna membentuk tim Live Recording dan Live Streaming yang akan turun dalam setiap pelaksanaan kegiatan pengabdian tersebut.

Pada mulanya tim dosen IKADO diwakili bapak Timothy John Pattiasina, ST., M.Kom. selaku ketua tim pengabdian, dengan dibantu 3 (tiga) orang dosen yaitu bapak Raymond Sutjiadi, ST., M.Kom., bapak Benny Rahmawan Noviadji, S.Sn., M.Sn. dan bapak Edwin Meinardi Trianto, S.Kom., M.Kom. yang bertindak selaku anggota. Disamping itu, tim pengabdian IKADO juga melibatkan mahasiswa dari masingmasing fakultas untuk diajak dalam tiap pelaksanaan kegiatan tersebut. Berdasarkan hasil rapat dari tim pengabdian IKADO maka disepakati untuk pelaksanaan Live Recording akan dilakukan pada tiap hari Jumat di GPIB Bahtera Hayat Surabaya, dan dilanjutkan dengan proses editing dan upload video hasil perekaman melalui Youtube Channel yang akan dibuatkan oleh tim IKADO untuk pihak gereja GPIB Bahtera Hayat Surabaya, pada hari Sabtu keesokan harinya. Di hari Minggu pagi pukul 07.00 WIB, video rekaman tersebut diharapkan dapat ditayangkan serta dilihat oleh seluruh warga jemaat GPIB Bahtera Hayat Surabaya, untuk melaksanakan kegiaran Ibadah Minggu dirumah masing-masing.

Sesuai dengan hasil pembicaraan dan kesepakatan yang telah dicapai sebelumnya oleh pihak IKADO Surabaya serta pihak GPIB Bahtera Hayat Surabaya, maka pelaksaan recording mulai dilakukan pada hari Jumat, 27 Maret 2020 Pkl. 18.00 WIB. Persiapan yang dilakukan oleh tim IKADO dimulai dari menyiapkan perangkat lunak serta perangkat keras yang akan digunakan dalam proses pengambilan gambar serta suara pada saat pelaksanaan Ibadah Live Recording. Perangkat lunak yang digunakan terdiri dari Corel Video 
Studio 2019 [1] dan Wondershare Uni Converter [2] yang dipakai untuk proses editing, rendering hingga converting video hasil perekaman yang dilakukan. Disamping itu tim IKADO juga menggunakan perangkat lunak Audacity [3] yang merupakan free open source, cross-platform software untuk dipakai sebagai perangkat lunak sound editor.

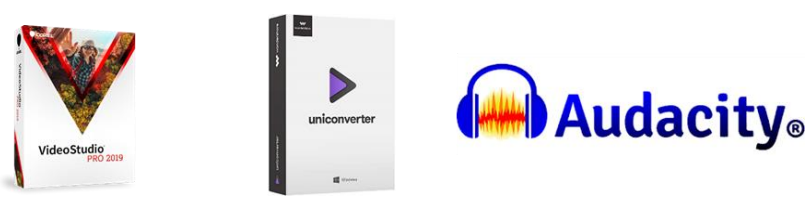

Gambar 3. Perangkat Lunak Kebutuhan Live Recording

Disamping itu untuk menjamin kualitas suara dan gambar yang dihasilkan dalam video Ibadah Minggu, tim IKADO memakai perangkat keras yang terdiri atas smartphone Galaxy S10 plus untuk media rekam video dan Soundcard Behringer UCA202 USB Audio Interface [4], sebagai media rekam suara dari mixer yang dimiliki oleh pihak gereja, yang selanjutnya akan dihubungkan dengan PC dan dilakukan proses editing.

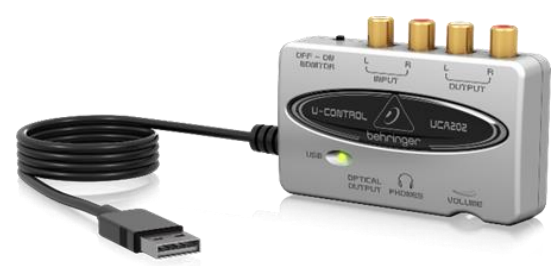

Gambar 4. Soundcard Behringer UCA202 USB Audio Interface

Dari pihak gereja GPIB Bahtera Hayat sendiri telah mempersiapkan sebuah studio yang dapat dipakai oleh tim IKADO dalam proses pengambilan video baik secara Live Recording maupun Live Streaming Ibadah Minggu tersebut. Pada saat pelaksanaan perekaman video Live Recording berlangsung, tim IKADO dalam hal ini 2 (dua) orang mahasiswa IKADO Surabaya yang dilibatkan membantu untuk mengarahkan majelis yang bertugas agar dapat mengikuti alur dan prosedur sesuai dengan tata ibadah hari minggu bersahaja yang telah ditetapkan oleh pihak gereja. Sedangkan bapak Timothy John dan 3 orang dosen lainnya, yaitu bapak Benny Rahmawan, bapak Raymond Sutjiadi serta bapak Edwin Meinardi Trianto bertugas sebagai cameramen dan sound engineer, yang memastikan bahwa pengambilan gambar serta suara dalam Live Recording dapat optimal.

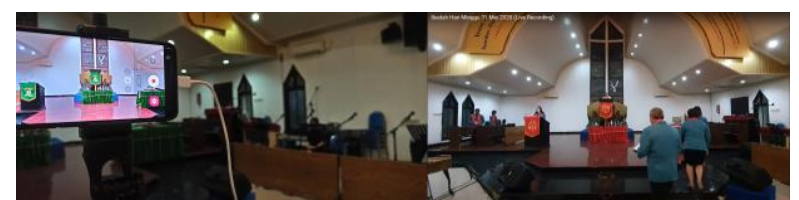

Gambar 5. Suasana pengambilan video Live Recording

Pelaksanaan perekaman video Ibadah Minggu Live Recording memakan waktu kurang lebih 50 menit. Setelah proses tersebut selesai, pada keesokan harinya, Sabtu 28 Maret 2020, tim IKADO mulai melakukan proses editing video dan suara yang mengambil tempat di kampus IKADO Surabaya.
Kedua mahasiswa/i yang dilibatkan menyiapkan registrasi Youtube Channel yang mengatasnamakan gereja (https://www.youtube.com/c/GPIBBahteraHayatSurabay a), yang akan dipakai oleh pihak GPIB Bahtera Hayat Surabaya sebagai sarana media online untuk di akses jemaat pada tiap hari Minggu guna melaksanakan peribadahan di rumah jemaat masing-masing. Tim dosen IKADO sendiri pertama kali melakukan proses editing suara dari video yang telah berhasil direkam sebelumnya, dilanjutkan dengan proses editing video dengan proses rendering dan konversi hasil rendering video. Seluruh proses tersebut mulai dari editing hingga converting kurang lebihnya menghabiskan waktu sekitar 4 (empat) jam.

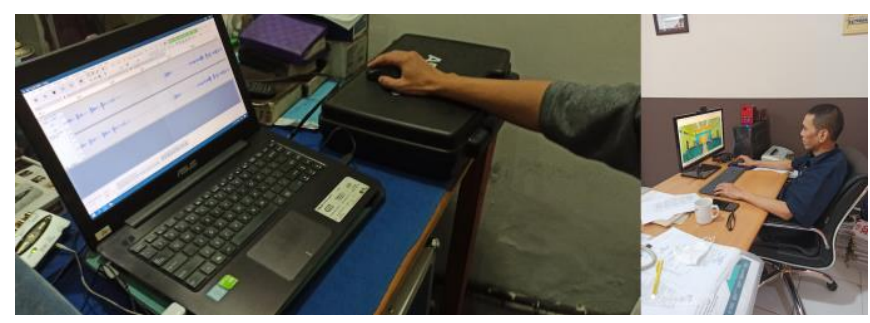

Gambar 5. Proses sound \& video editing di IKADO

Setelah seluruh proses berhasil dilakukan, tim dosen melanjutkan proses unggah video ke Youtube Channel yang telah disiapkan sebelumnya dan memberikan pengaturan jadwal agar video Ibadah Minggu Live Recording tersebut dapat tampil pada hari dan jam Ibadah yang telah ditetapkan (Minggu, 29 Maret 2020 pada pukul 07.00 WIB). Selanjutnya di hari Minggu, 29 Maret 2020, tiap anggota jemaat GPIB Bahtera Hayat Surabaya sudah dapat mengakses link/tautan dari Youtube Channel gereja untuk melakukan Ibadah Minggu di rumah masing-masing.

Pelaksanaan kegiatan pengabdian masyarakat di GPIB Bahtera Hayat sendiri pada awalnya dijadwalkan selesai sampai dengan bulan Juli tahun 2020. Akan tetapi seiring dengan perkembangan situasi dan kondisi terkait pandemi COVID-19 di wilayah Surabaya dan sekitarnya, serta peraturan yang telah ditetapkan oleh pemerintah kota Surabaya, mengakibatkan pelaksanaan kegiatan pengabdian masyarakat tersebut diperpanjang hingga bulan Desember 2020. Pada akhir tahun 2020, pihak GPIB Bahtera Hayat Surabaya kembali meminta kesediaan kepada tim IKADO Surabaya untuk kembali menangani proses Ibadah Minggu secara Live Recording dan Live Streaming yang dimulai lagi pada bulan Januari hingga bulan Maret tahun 2021. Tim IKADO Surabaya menyanggupi hal tersebut dan melakukan penambahan 3 (tiga) personil dosen yang dilibatkan selaku anggota, yaitu bapak Briantito Adiwena, ST., MT., bapak Arjuna Bangsawan, S.Sn., M.Pd., dan bapak Eddy Triswanto Setyoadi, ST., M.Kom. Dalam pelaksanaan dari bulan Agustus hingga Desember tahun 2020, tim IKADO juga mencoba untuk melaksanakan proses Ibadah Minggu secara Live Streaming. Tentunya dengan tetap memperhatikan protokol kesehatan yang berlaku untuk setiap kegiatan. Keterlibatan mahasiswa juga terus dilakukan oleh tim IKADO dengan mengajak beberapa mahasiswa baik dari Fakultas Teknologi Informasi maupun Fakultas Desain secara bergantian dalam 
tiap pelaksanaan kegiatan pengabdian. Pada pelaksanaan Ibadah Minggu secara Live Streaming, tim IKADO melakukan di tiap hari Minggu, sesuai dengan jadwal ibadah yang berlangsung (Pkl. 08.00 WIB - selesai). Beberapa peralatan tambahan juga disiapkan oleh tim IKADO, dalam hal ini berupa tambahan perangkat untuk jaringan serta kamera yang akan dipakai dalam proses pengambilan video secara Live Streaming. Untuk kebutuhan perangkat keras yang dibutuhkan dalam pelaksanaan Live Streaming terdiri dari 4 (empat) perangkat smartphone android, 1 (satu) kamera DSLR, HDMI extender, kabel LAN dan HDMI masing-masing memiliki panjang 50 Meter dan 1 (satu) buah harddisk eksternal untuk backup data dengan kapasitas 500 GB. Masing-masing peralatan tersebut disiapkan oleh tim IKADO Surabaya bekerjasama dengan pihak gereja GPIB Jemaat "Bahtera Hayat" Surabaya.
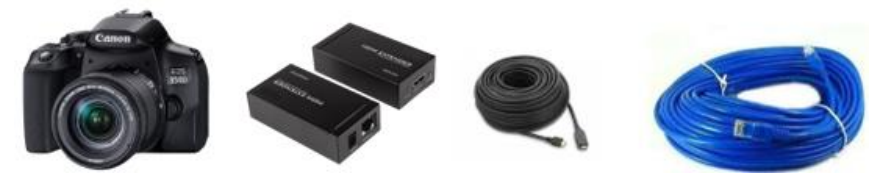

Gambar 6. Peralatan Kebutuhan Live Streaming

Dalam tiap pelaksanaan kegiatan Ibadah secara Live Streaming sampai dengan bulan Maret tahun 2021, tim IKADO sendiri tetap diwakili oleh bapak Timothy John Pattiasina, dengan dibantu beberapa dosen serta mahasiswa secara bergantian, disesuaikan dengan jadwal yang telah disusun sebelumnya. Pelaksanaan Live Streaming sendiri memakan waktu persiapan dari Pkl. 07.00 WIB hingga akhir ibadah sekitar Pkl. 10.30 WIB. Pelaksanaan Ibadah Minggu secara Live Streaming ini hanya berlangsung dalam satu hari yang sama, dikarenakan pelaksanaannya yang langsung ditayangkan melalui Youtube Channel yang telah dimiliki oleh GPIB Bahtera Hayat Surabaya.

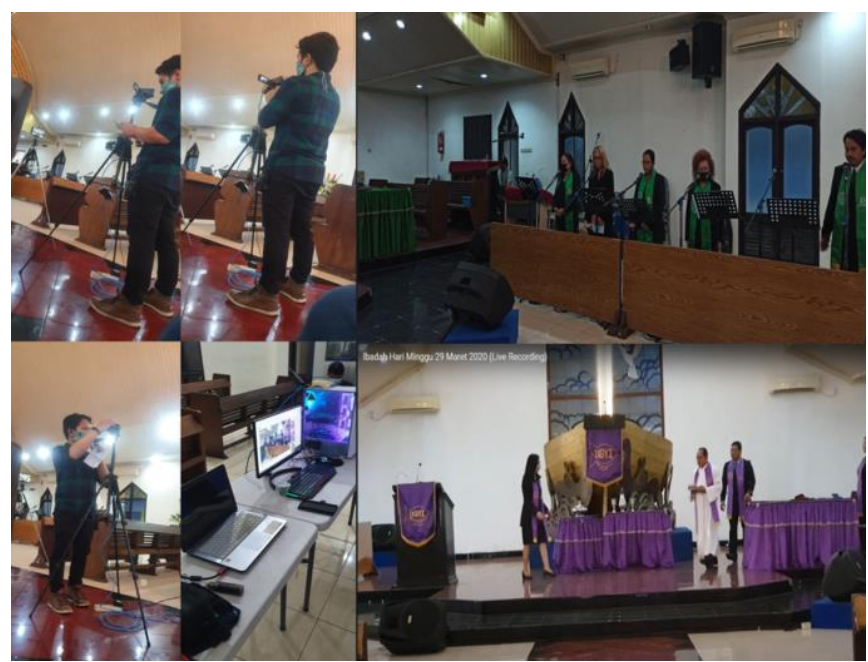

Gambar 7. Suasana Pelaksanaan Ibadah Live Streaming

Pada saat pelaksanaan Ibadah Minggu secara Live Streaming berlangsung, tim IKADO dalam hal ini 2 (dua) orang mahasiswa IKADO Surabaya yang dilibatkan membantu untuk mengarahkan majelis yang bertugas agar dapat mengikuti alur dan prosedur sesuai dengan tata ibadah hari minggu bersahaja yang telah ditetapkan oleh pihak gereja. Sedangkan tim dosen IKADO tetap menjalankan tugasnya selaku cameramen dan sound engineer secara bergantian sesuai dengan jadwal dan surat tugas yang telah disusun sebelumnya.

\section{PELAKSANAAN KEGIATAN}

Sesuai dengan surat tugas yang diberikan, maka tim IKADO menyelesaikan proses pelaksanaan Ibadah Minggu Live Streaming dan Live Recording dalam waktu kurang lebih 1 (satu) tahun sejak April 2020 hingga Maret tahun 2021. Tim IKADO telah menyelesaikan 52 video yang diambil secara Live Recording maupun Live. Kendala yang dihadapi oleh tim IKADO hanya menyangkut permasalahan jaringan yang terkadang tidak stabil pada saat pengambilan video secara Live Streaming, serta kondisi cuaca di kota Surabaya yang tidak menentu. Sedangkan untuk pelaksanaan Ibadah Minggu secara Live Recording, tim IKADO sudah tidak menemukan kendalam sama sekali dalam melakukan tugas dan tanggung jawabnya.

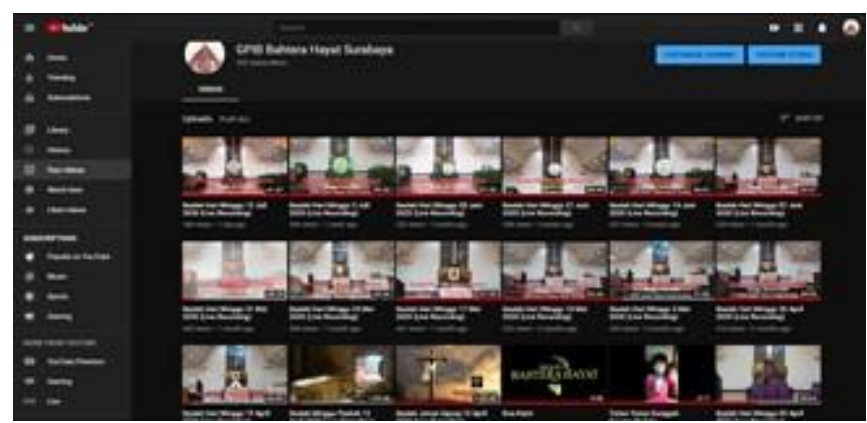

Gambar 8. Tampilan Youtube Channel GPIB Bahtera Hayat Surabaya

Pada tiap pelaksanaan kegiatan pengabdian masyarakat di GPIB Bahtera Hayat Surabaya, kepala P3M IKADO Surabaya tetap mengeluarkan surat tugas, dan disesuaikan dengan masing-masing anggota tim IKADO yang diberangkatkan. Kehadiran dosen dalam tim cukup membantu untuk mengarahkan mahasiswa dalam proses pembelajaran mereka terkait multimedia dan sound engineering. Disamping itu, tim dosen IKADO juga tetap melakukan pengajaran on the spot kepada pegawai maupun jemaat yang ingin belajar tentang cara merekam video yang baik. Diharapkan dari pembelajaran ini kedepannya pihak gereja GPIB Bahtera Hayat Surabaya dapat memiliki opsi dari jemaat yang dapat dilibatkan untuk kegiatan semacam ini. Seluruh proses pelaksanaan Ibadah Minggu dalam bentuk Live Streaming maupun Live Recording di GPIB Bahtera Hayat Surabaya telah dilaksanakan oleh tim IKADO Surabaya, dan berakhir pada pelaksanaan Ibadah Minggu Live Streaming tanggal 28 Maret 2021. Akan tetapi dari pihak GPIB Bahtera Hayat Surabaya tetap meminta kesediaan dari tim IKADO apabila dari pihak gereja perlu untuk memperpanjang pelaksanaan Ibadah Minggu mereka, dengan pertimbangan perkembangan pandemi Covid-19 di kota Surabaya. 


\section{KESIMPULAN}

Berdasarkan hasil evaluasi kegiatan yang dilakukan mulai tahun 2020 hingga tahun 2021, tim IKADO Surabaya terus memberikan masukan dalam bentuk rekomendasi kepada pihak GPIB Bahtera Hayat Surabaya guna menunjang proses pelaksanaan Ibadah Minggu baik secara Live Streaming maupun Live Recording apabila memang dirasa perlu untuk diperpanjang. Salah satunya adalah pelatihan pegawai serta pemuda-pemudi dari anggota jemaat terkait dengan pelaksaan Ibadah Minggu secara daring ini. Pihak Majelis Jemaat GPIB Bahtera Hayat Surabaya menyambut gagasan tersebut dengan melibatkan anggota pemuda di gereja mereka dalam setiap pelaksanaan proses Ibadah Minggu secara Live Streaming

\section{REFERENSI}

[1] Corel, "Looking to Download VideoStudio 2019?," https://www.corel.com/, 2021. https://www.corel.com/en/old-versions/videostudio2019/ (accessed Apr. 23, 2021).

[2] Wondershare, "Wondershare UniConverter (Video Converter Ultimate) A one-stop video converter for any media file and memories," https://videoconverter.wondershare.com/, 2021. https://videoconverter.wondershare.com/ (accessed Apr. 23, 2021).

[3] Audacity, "Free, open source, cross-platform audio software," https://www.audacityteam.org/, 2021. https://www.audacityteam.org/ (accessed Apr. 23, 2021).

[4] behringer.com, "UCA202: Ultra-Low Latency 2 In/2 Out USB/Audio Interface with Digital Output," https://www.behringer.com/, 2021. https://www.behringer.com/product.html?modelCode $=$ P0484 (accessed Apr. 23, 2021). maupun Live Recording. Kedepannya, tentu saja diharapkan akan mampu untuk dibentuk menjadi tim internal gereja yang bertanggung jawab pada tiap pelaksanaan Ibadah Minggu di GPIB Bahtera Hayat Surabaya.

Bagi Institut Informatika Indonesia (IKADO) Surabaya sendiri, keterlibatan mahasiswa dalam kegiatan pengabdian kepada masyarakat seperti yang telah dilaksanakan selama masa pandemi ini akan terus ditingkatkan di kemudian hari, meskipun masa pandemi sudah berlalu. Hal tersebut dirasa penting sebagai salah satu bekal penerapan ilmu yang telah diperoleh oleh mahasiswa IKADO, yang dapat langsung mereka terapkan ditengah-tengah kehidupan masyarakat disekitar mereka. 